International Journal of Managing Information Technology (IJMIT) Vol.10, No.4, November 2018

\title{
HYBRID ROLE OF SOFT INNOVATION RESOURCES: Finland's Notable RESURgenCE In The DigitaL ECONOMY
}

\author{
Yuji Tou ${ }^{1}$, Chihiro Watanabe ${ }^{2,3}$, Leena Ilmola ${ }^{4}$, Kuniko Moriya $^{5,6}$, Pekka Neittaanmäki ${ }^{7}$ \\ ${ }^{1}$ Dept. of Ind. Engineering \&Magm., Tokyo Institute of Technology, Tokyo, Japan \\ ${ }^{2}$ Faculty of Information Technology,University of Jyväskylä, Finland \\ ${ }^{3,4}$ International Institute for Applied Systems Analysis (IIASA), Austria \\ ${ }^{5}$ Research and Statistics Department, Bank of Japan, Tokyo, Japan \\ ${ }^{6,7}$ Faculty of Information Technology, University of Jyväskylä, Finland
}

\begin{abstract}
Finland and Singapore are easy to compare, they are the same size and have similar positions as global digital leaders. however, their performance is differing a lot. from 2006 to 2013, Singapore's GDP growth rate was tenfold compared to Finland. four years later, in 2017 Finland is exceeding the growth rate of Singapore. what are the reasons for the success of Finland? An empirical analysis of the factors contributing to GDP growth and the effects of the policy change was conducted. It was demonstrated that increase of export did not explain growth, but shifts in capital formation did. New dynamics was revealed that was triggered by the removal of structural impediments (hindrances) and by increasing use of soft innovation resources. The virtuous cycle of increase of uncaptured GDP, increased multifactor productivity and growth of tangible capital and GDP was described. An insightful suggestion for activating a hybrid role for soft innovation resources in the digital economy was thus provided.
\end{abstract}

\section{KEYWORDS}

Digital economy, soft innovation resources, multifactor productivity, competitiveness pact, Finland and Singapore

\section{INTRODUCTION}

The dramatic advancement of the Internet has generated the digital economy, which has provided us with extraordinary services and welfare never anticipated before [1]. However, they cannot be captured through GDP data, which measure economic values. This Internet-emerged added value of providing people with utility and happiness, which extends beyond economic value, is defined as uncaptured GDP [2] [3] [4].

In Finland, the popular tendency is to explain growth with growing exports. Some part of this is true; net export of Finland has grown, but relatively little. In 2017 export's contribution was less than $20 \%$ of the total GDP. In analysis of the components of the GDP growth of Singapore and Finland, one significant difference was found out; in Finland gross fixed capital (GC) was 1.49 (GDP was 2.76) but in Singapore it was only -0.42 (GDP was 2.53) [5]. The analysis published in the previous number of this journal [5] [6] revealed that from components of GC, Finland was able 
International Journal of Managing Information Technology (IJMIT) Vol.10, No.4, November 2018

to increase gross tangible capital (GTC) when gross service capital (GSC) was decreasing as demonstrated in Table 1.

Table 1. Contribution to expenditure on GDP growth in Finland and Singapore (2013-2017) - real growth rate $(\%$ p.a $)$.

\begin{tabular}{l} 
GTC contribution to GDP $(\% p . a)$ \\
\cline { 2 - 7 }
\end{tabular}

Sources: World economic outlook database (IMF, 2017). National accounts of Finland (Statistics Finland, 2018), National accounts of Singapore (Department of statistics Singapore, 2018).

Values in 2017 are based on IMF estimates as of Oct. 2017. Components shares are adjusted to IMF statistics using the share of respective statistics.

This implies that another common perception should be challenged; R\&D investments are supposed to increase competitiveness and thus the growth of GDP. In the case analyzed this rule was not applicable. Investments in the R\&D and development of the stock of intellectual property products (IPP) had decreased in Finland. (Unlike in Singapore that invested significantly in R\&D). In Finland especially companies had year after year decreased traditional R\&D expenditure since 2008 [6].

In our previous studies [5] and in the most recent paper [6]it has been analyzed globalinformation and communication technology (ICT) companies' performance and their new digital platforms based innovation mode, that is called usage of Soft Innovation Resources (SIRs).

While Finland and Singapore have been maintaining world digital leaders position [7], both countries demonstrated interlaced contrast. Finland enjoyed a high level of happiness/welfare under the stagnation while Singapore accomplished higher economic growth in the lower level of happiness/welfare [8]. This observation reminds us a plausible view that "well-being of the Finnish people has developed in a more positive direction than one might conclude by GDP data" [9] and prompts us a hypothetical view that Finland has depended on un captured GDP much largely than Singapore by spinning-off from traditional co-evolution of economic value, traditional ICT development and GDP growth to new co-evolution of people's preferences shifting to a suprafunctionality beyond economic value encompassing socio, cultural and emotional values, advancement of the Interne for further functionality and increasing dependence on un captured GDP as illustrated in Fig. 1[3].

It is claimed that use of SIRs is a novel innovation mode applied in the digitalized and ICT firms. Authors in previous studies described this hypothetical view [4] and identified that while such transformative circumstances in the digital economy results in productivity decline, global ICT firms endeavor to survive by spontaneous creation of un captured GDP by harnessing the vigor of 
International Journal of Managing Information Technology (IJMIT) Vol.10, No.4, November 2018

SIRs [5]. SIRs consist of the Internet based (that permeates into broad ICT in the digital platform economy [8]) resources that have been either sleeping or untapped or are results of multisided interaction in the markets where consumer is looking for functionality beyond economic value. The common feature of SIRs is that they are not accountable in the traditional GDP terms [8] [10].

One more finding from our previous work is important background to the study described in this paper. It has been demonstrated that removal of structural impediments of GDP growth such as conflict between public, employers and labor union, disparity of gender, and also increasing discrepancy toward an aging society. Thus, spontaneous creation of un captured GDP through effective utilization of SIRs contributes to growth by its hybrid function as illustrated in Fig. 1[5].

It was then postulated that the recent reversal trend in GDP growth of digital leaders in Finland and Singapore could be attributed to this hybrid function, and attempted to demonstrate this hypothetical view [6].

First it was identified that Finland's recent GDP growth recovery could largely be attributed to its GC to which negative contribution in Singapore as demonstrated in Table 1 [5]

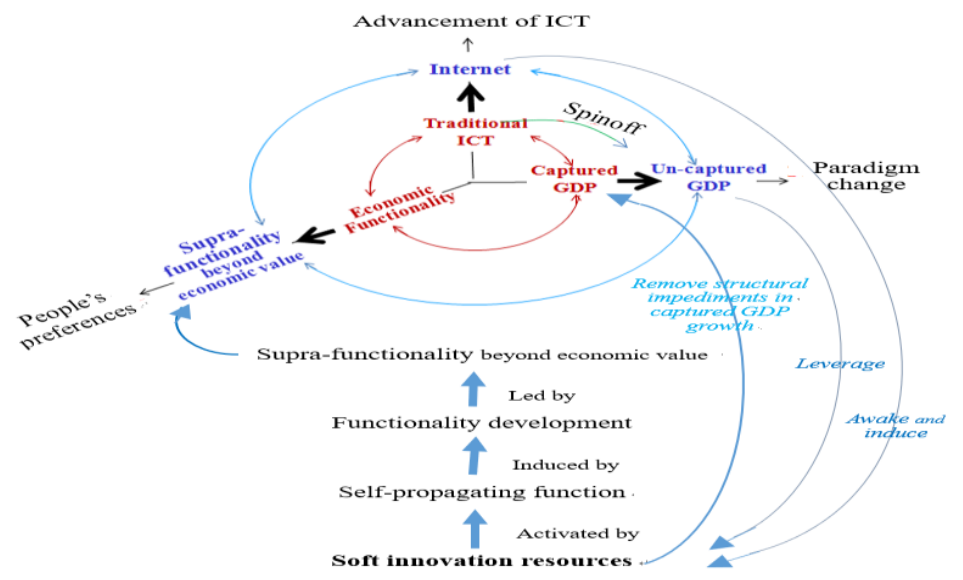

Figure 1. The dynamism of hybrid role of soft innovation resources: Creation of un captured GDP and removing of structural impediments in captured GDP growth.

Then it was identified that contrary to an increasing share in Singapore, Finland has been shifting to less dependence on GSC (IPP, majority of which is R\&D) in its GC formation. It was postulated that this can be attributed to SIRs substitution for GSC. Furthermore, our previous findings reveal that SIRs spilled-over to GTC and contributed to removing structural impediments of GTC's increase leading to GDP growth as illustrated in Fig. 2 [6]. Here, un captured GDP seems to have taken a role of paving the path for SIRs substitution for GSC and then contribution to GTC by spilling-over to it.

Based on these demonstrations, authors postulated a dynamism of virtuous cycle between SIRs and un captured GDP creation through aforementioned co-evolution, at the same time removing structural impediments in captured GDP growth [6]. 
International Journal of Managing Information Technology (IJMIT) Vol.10, No.4, November 2018

Thus our earlier work implies that there is a dynamism of hybrid roles of SIRs: sophisticated virtuous cycle between SIRs and uncaptured GDP creation through aforementioned co-evolution, at the same time removing structural impediments in captured GDP growth.

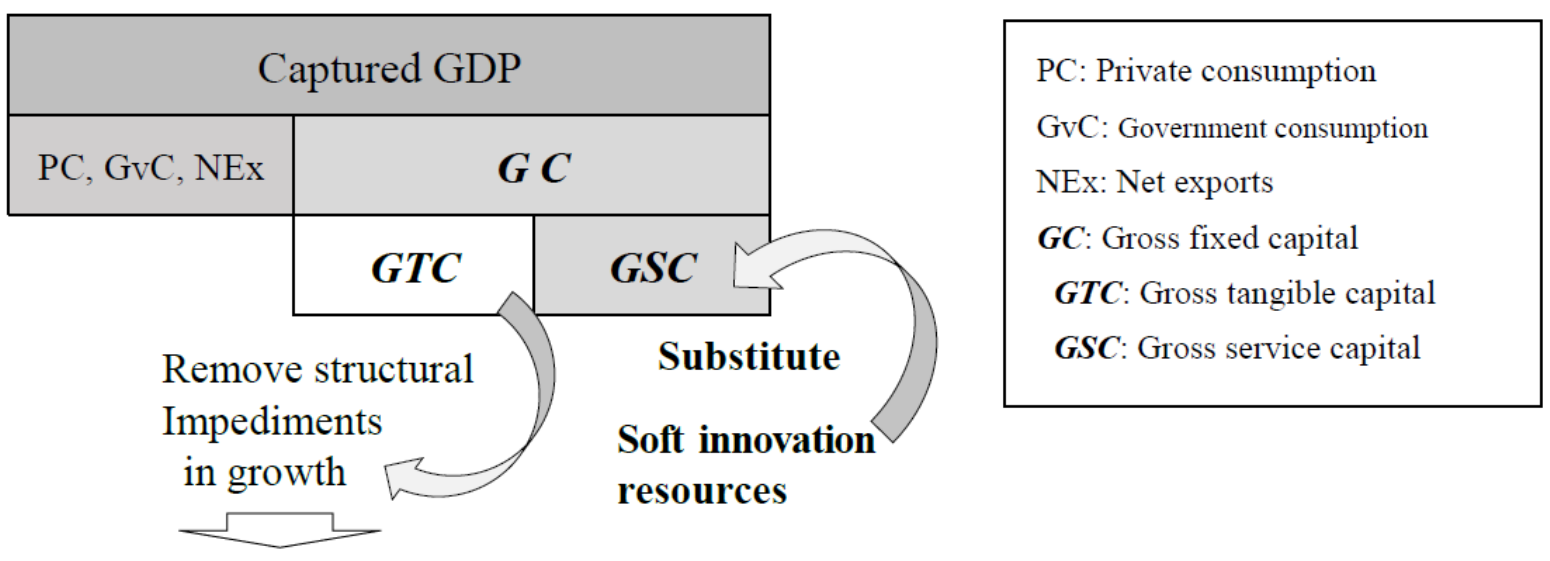

Captured GDP increase

Figure 2. Mechanism of SIRs removing structural impediments in GTC increase.

Source: Tou et al. (2018) [6].

However, a dynamism that enabled such a miraculous function has remained beyond the reach.This paper attempts to elucidate inside the black-box of this function. Historically Finland depends largely on multifactor productivity (MFP $=$ TFP: which represents economic efficiency) [11][12] to which own R\&D, spillover technology, demand creation, and learning effect play leading role [13]. Finland has been good at crises by transforming them into a springboard for new innovation by substituting it for constrained resources [3].Finland also incorporates institutional elasticity that assimilates spillover technology into its own system [4]. However, this elasticity has been long subdued by the aftermath of the economic stagnation after the Lehman shock in 2018 [14].

Note While Finland incorporated highlevel of "firm-level technology absorption capacity and ranked 6thin the world (out of 140 countries) in 2013, it devaluated to 10th in 2016 (The Global IT Report, WEF).

With these understandings, an empirical analysis focusing on the interactions among factors contributing to GDP growth particularly of MFP growth and its constitutes over the last quarter century and the effects of the policy decisions suchas Competitiveness Pact on Finland's resurgence was conducted. The Pact was enacted in June 2016 aiming at reactivating nation's indigenous elasticity [5]. 
International Journal of Managing Information Technology (IJMIT) Vol.10, No.4, November 2018

Note The 'Competitiveness Pact', a tripartite labour market agreement, was signed in June 2016 after over a year of difficult negotiations. The Pact involves a nationally and internationally exceptional deterioration of workers' terms and conditions. The negotiation process had disruptive repercussions on social partner organisations and seemingly brought the traditionally centralized collective bargaining system to an end.

https://www.eurofound.europa.eu/publications/article/2016/finland-tripartite-competitivenesspact-signed

How SIRs are making this happen? How the Competitiveness Pact awoke Finnish latent institutional elasticity and activated SIRs? This paper attempts to explore inside the black-box of this function by looking closelyat the role of MFP in growth.

An insightful suggestion for activating a hybrid role for soft innovation resources in the digital economy was thus provided.

Section 2 analyzes inducing role of MFP. Contributors to MFP growth and GTC increase are analyzed in Section 3. Section 4 demonstrates uncaptured GDP's role in paving the path for substitution. Section 5 analyzes dynamism in removing structural impediments in GTC growth. Section 6 summarizes the noteworthy findings, policy suggestions, and future research.

\section{Inducing Role Of Multifactor Productivity}

Statistics of Finland in its "Productivity Surveys" (30 Nov. 2017) [11] has analyzed contribution of production factors to GDP growth rate over the period of 1976-2016 by decomposing contribution of labor, capital and MFP as illustrated in Fig. 3.

Note In line with 2008SNA, it classified R\&D contribution to GDP growth rate in the contribution of capital not in MFP as traditionally included. In addition, it treated total contribution by labor, capital and MFP as change rate of value added while GDP $=$ Value added + taxes on products + subsidies on products.

MFP is a measure of economic efficiency which is not explained by growth in inputs (labor and capital). MFP growth depicts not only technological development and increased efficiency but also the effects from improved quality of inputs, management, logistics and organization [13].

Traditionally Finland has been good at managing crises. A distinct feature of Finnish economic growth, especially since the Second World War, can be attributed to MFP growth[11][12]. Therefore, MFP growth rate has strong correlation with GDP growth rate in Finland as demonstrated in Table 2.

Table 2. Correlation between MFP and GDP growth rate in Finland (1994-2016).

$$
\begin{aligned}
& G G R=0.85+1.22 \text { MFPGR } \quad \text { adj. } R^{2} 0.917 \text { DW1.66 } \\
& \text { (4.05) (15.60) } \\
& G G R=1.09+1.24 M F P^{*} G R \quad \text { adj. } R^{2} 0.889 \mathrm{DW} 1.36
\end{aligned}
$$


International Journal of Managing Information Technology (IJMIT) Vol.10, No.4, November 2018

Where GGR: Real GDP growth rate, MFPGR: MFP growth rate including contribution of R\&D, and MFP*GR: MFP growth rate not including contribution of R\&D.

The figures in parentheses indicate the t-statistics: all are significant at the $1 \%$ level. Consequently, MFP growth rate highly depends on GDP growth rare as shown in Table 3.

Table 3. Correlation between GDP growth rate and MFP growth ratein Finland (1994-2016).

$$
\begin{aligned}
M P F G R= & -0.55+0.76 G G R \quad \text { adj. } R^{2} 0.917 \mathrm{DW} 1.80 \\
& (-2.95)(15.60)
\end{aligned}
$$

The figures in parentheses indicate the t-statistics: all are significant at the $1 \%$ level

Productivity Survey's MFP growth rate analysis remained up until 2016, based on this correlation and utilizing IMF's GDP growth rate estimate by 2018 (Fig. 4-1) [15], MFP growth rate by 2018 can be estimated as illustrated in Fig. 4-2. Fig. 4 illustrates this parallel path in Finland over the period of 1975-2018.

Fig. 4 also demonstrates trend in R\&D intensity (R\&D expenditure per GDP) over the period of 1981-2018 (Fig. 4-3) which provides an intriguing contrast between GDP and R\&D intensity during the period of resurgence (2015-2018). R\&D intensity maintained a parallel path with GDP and changed to decline from 2010 as a consequence of GDP decrease after the Lehman shock in 2008. While GDP changed to increase from 2015, R\&D intensity continued to decline. This suggests that Finnish resurgence can be attributed to a new dynamism: economic resurgence in the declining R\&D.

\section{GDP growth rate}

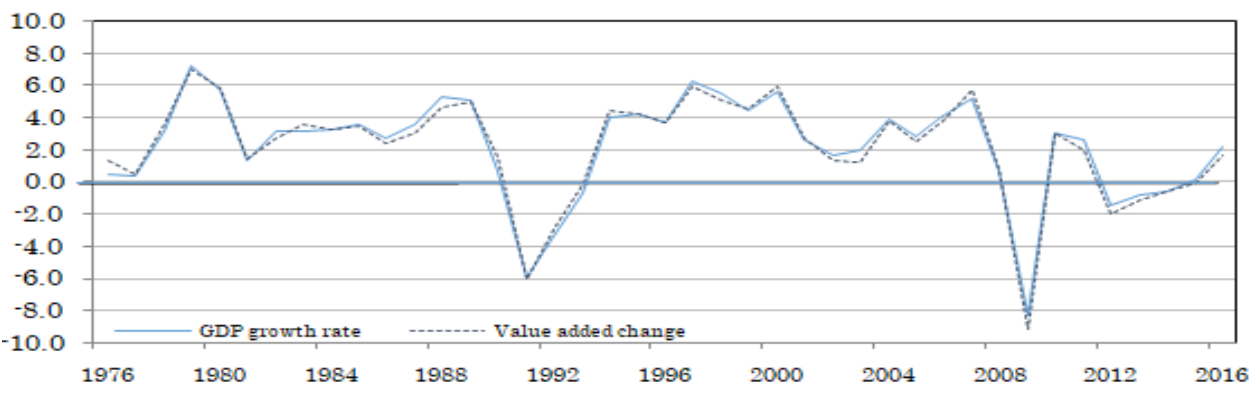

\section{Contribution of labor}

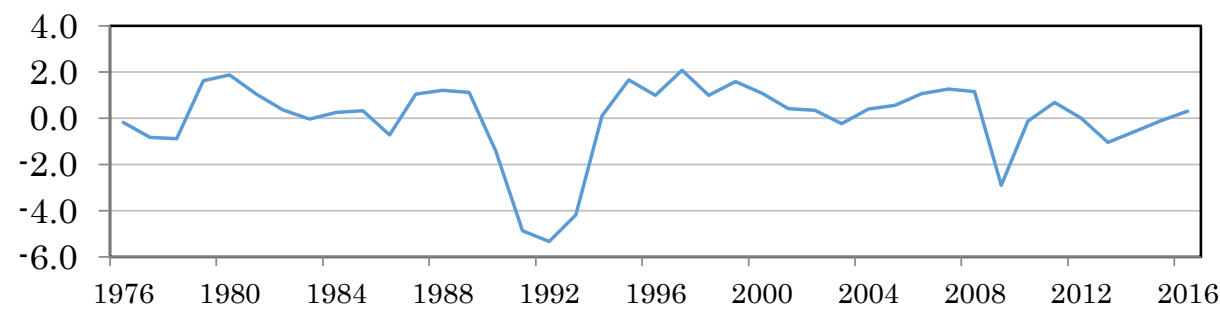


International Journal of Managing Information Technology (IJMIT) Vol.10, No.4, November 2018
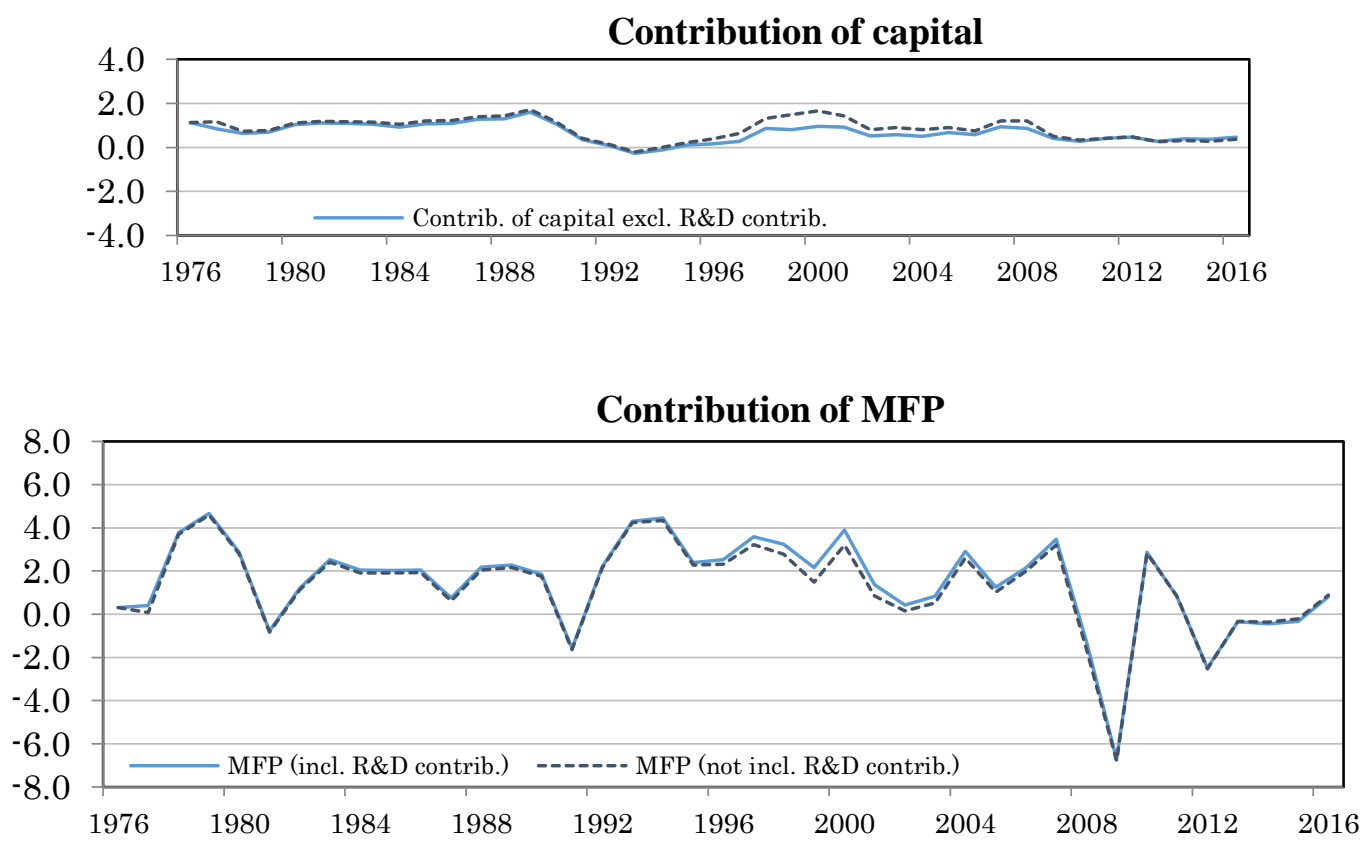

Figure 3. Trends in factors contributing to GDP growth rate in Finland (1976-2016) - \% p.a. Source: Productivity Surveys (Statistics of Finland, 2017) [11].

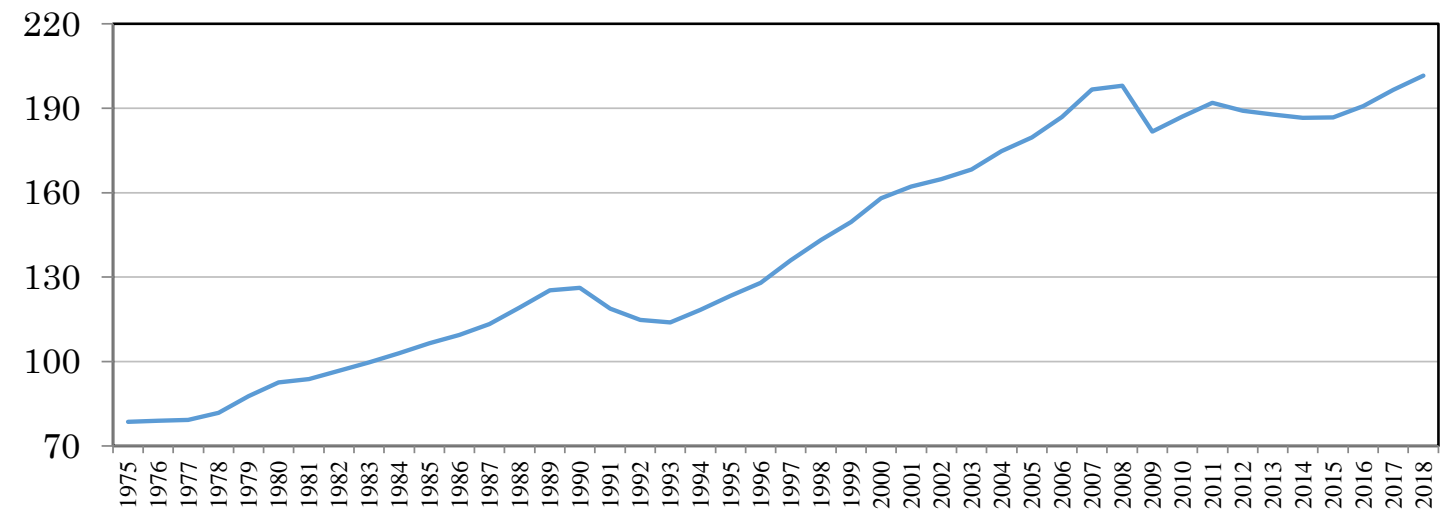

Figure 4-1. Trend in real GDP in Finland (1975-2018).

Source: IMF (2018) [15]. 
International Journal of Managing Information Technology (IJMIT) Vol.10, No.4, November 2018

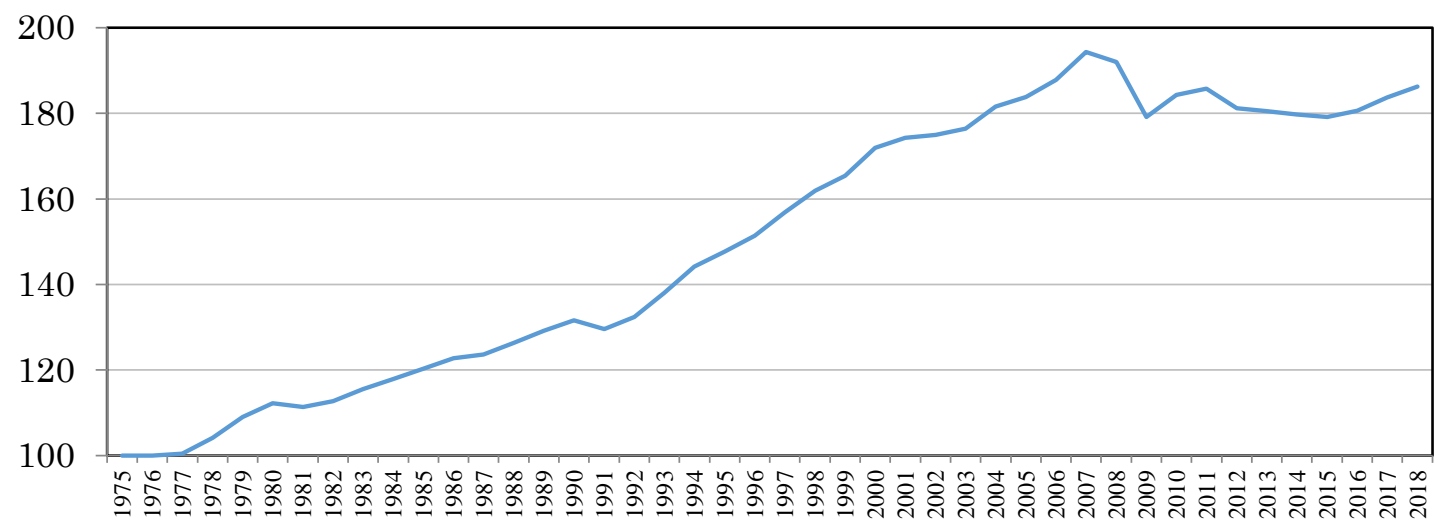

Figure 4-2. Trend in MFP in Finland (1975-2018)- Index: $1975=100$.

Sources: 1975-2016: Productivity Surveys (Statistics of Finland, 2017) [11].

2017, 2018: Authors' estimate based on the above and IMF (2018) [15].

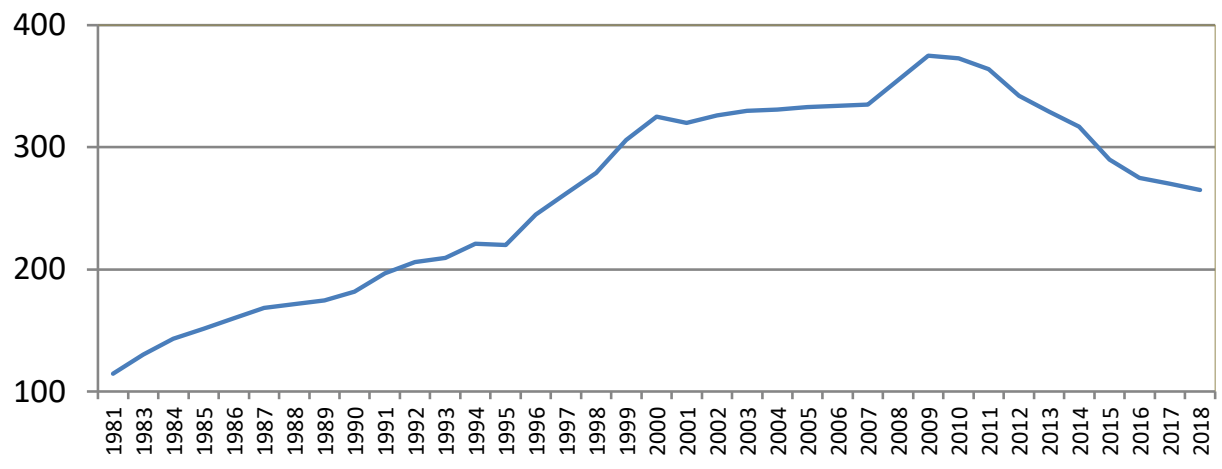

Figure 4-3. Trend in R\&D intensity in Finland (1981-2018).

Source: OECD (2018) [16].

Figure 4. Trends in real GDP, MFP and R\&D intensity in Finland (1975-2018).

\section{CONTRIbUtors To MFP Growth AND GTC InCREASE}

\subsection{CONTRIBUTORS To MFP GROWTH}

Previous analyses of Section 2 suggest that MFP growth, particularly its shift to upswing from 2016 should be the core contributor to Finnish economic resurgence from 2016.

As suggested in Section 1, given that this resurgence can largely be attributed to the Competitive Pact in June 2016 that spurred SIRs substitution for GSC and spill-over to GTC, this dynamism in MFP is analysed based on historical trends in Finnish fundamental economic structure as tabulated in Table 4. 
International Journal of Managing Information Technology (IJMIT) Vol.10, No.4, November 2018

Table 4. Trends in factors governing MFP in Finland (1994-2018).

\begin{tabular}{|c|c|c|c|c|c|c|c|c|c|c|c|}
\hline Period & Time & \begin{tabular}{|c|} 
MFP $^{*}$ \\
(not incl. $R \& D$ \\
contrib.)
\end{tabular} & \begin{tabular}{|l}
\multicolumn{1}{|c|}{ MFP } \\
(incl. $R \& D$ \\
contrib.) \\
\end{tabular} & Real GDP & $\begin{array}{c}\text { R\&D } \\
\text { intensity }\end{array}$ & $\begin{array}{l}\text { Real } \\
\text { expenditure }\end{array} \mid$ & $\begin{array}{c}\text { Real GDP } \\
\text { Growth } \\
\text { rate }\end{array}$ & \begin{tabular}{c|} 
Real $\mathrm{R} \& \mathrm{D}$ \\
expenditure \\
Growth rate
\end{tabular} & $\begin{array}{c}\text { Internet } \\
\text { dependence }\end{array}$ & \begin{tabular}{|c|} 
Final \\
consumption \\
expenditure
\end{tabular} & $\mathrm{GTC} / \mathrm{GC}$ \\
\hline Year & $t$ & $\begin{array}{l}M F P^{*} \\
(1975=100)\end{array}$ & $\begin{array}{l}M F P \\
(1975=100)\end{array}$ & $\begin{array}{|lll|}V \text { (bil. } & \text { E } & \text { at } \\
2010 \text { prices) }\end{array}$ & $\begin{array}{c}R V \\
\%\end{array}$ & \begin{tabular}{|l|}
$R$ (bil. E at \\
2010 prices) \\
\end{tabular} & $\begin{array}{c}G G R \\
\% \\
\end{array}$ & $\begin{array}{c}R V G R \\
\% \\
\end{array}$ & $\begin{array}{l}I \\
\% \\
\end{array}$ & \begin{tabular}{|l|}
$C($ bil. E at \\
2010 prices $)$ \\
\end{tabular} & $\begin{array}{l}K \\
\% \\
\end{array}$ \\
\hline 1994 & 1 & 141.9 & 144.2 & 118.4 & 2.21 & 2.6 & 3.9 & 9.8 & 4.9 & 94.7 & 80.2 \\
\hline 1995 & 2 & 145.2 & 147.7 & 123.4 & 2.20 & 2.7 & 4.2 & 3.8 & 13.9 & 98.9 & 80.6 \\
\hline 1996 & 3 & 148.5 & 151.4 & 127.9 & 2.45 & 3.1 & 3.7 & 15.4 & 16.8 & 102.1 & 80.9 \\
\hline 1997 & 4 & 153.3 & 156.8 & 135.9 & 2.62 & 3.6 & 6.3 & 13.6 & 19.5 & 105.6 & 80.5 \\
\hline 1998 & 5 & 157.6 & 161.9 & 143.3 & 2.79 & 4.0 & 5.4 & 12.0 & 25.5 & 109.7 & 80.6 \\
\hline 1999 & 6 & 159.9 & 165.4 & 149.7 & 3.06 & 4.6 & 4.4 & 14.5 & 32.3 & 112.9 & 78.3 \\
\hline 2000 & 7 & 165.0 & 171.9 & 158.1 & 3.25 & 5.1 & 5.6 & 12.2 & 37.3 & 114.9 & 77.9 \\
\hline 2001 & 8 & 166.5 & 174.2 & 162.2 & 3.20 & 5.2 & 2.6 & 1.1 & 43.1 & 118.0 & 77.3 \\
\hline 2002 & 9 & 166.7 & 175.0 & 164.9 & 3.26 & 5.4 & 1.7 & 3.6 & 62.4 & 121.0 & 77.0 \\
\hline 2003 & 10 & 167.6 & 176.4 & 168.2 & 3.30 & 5.6 & 2.0 & 3.4 & 69.2 & 125.1 & 76.2 \\
\hline 2004 & 11 & 171.9 & 181.6 & 174.8 & 3.31 & 5.8 & 3.9 & 4.3 & 72.4 & 128.8 & 77.1 \\
\hline 2005 & 12 & 173.7 & 183.9 & 179.7 & 3.33 & 6.0 & 2.8 & 3.2 & 74.5 & 132.5 & 77.1 \\
\hline 2006 & 13 & 177.1 & 187.8 & 186.9 & 3.34 & 6.2 & 4.1 & 4.3 & 79.7 & 136.7 & 77.1 \\
\hline 2007 & 14 & 182.8 & 194.3 & 196.6 & 3.35 & 6.6 & 5.2 & 5.4 & 80.8 & 140.6 & 78.0 \\
\hline 2008 & 15 & 180.0 & 192.0 & 198.0 & 3.55 & 7.0 & 0.7 & 6.8 & 82.5 & 143.4 & 77.6 \\
\hline 2009 & 16 & 167.7 & 179.1 & 181.7 & 3.75 & 6.8 & -8.3 & -3.1 & 83.7 & 141.3 & 75.9 \\
\hline 2010 & 17 & 172.4 & 184.3 & 187.1 & 3.73 & 7.0 & 3.0 & 2.4 & 86.9 & 144.3 & 75.9 \\
\hline 2011 & 18 & 173.9 & 185.8 & 191.9 & 3.64 & 7.0 & 2.6 & 0.2 & 88.8 & 147.1 & 77.8 \\
\hline 2012 & 19 & 169.5 & 181.1 & 189.2 & 3.42 & 6.5 & -1.4 & -7.4 & 90.0 & 147.7 & 78.6 \\
\hline 2013 & 20 & 168.9 & 180.5 & 187.7 & 3.29 & 6.2 & -0.8 & -4.6 & 91.6 & 147.7 & 78.3 \\
\hline 2014 & 21 & 168.3 & 179.7 & 186.6 & 3.17 & 5.9 & -0.6 & -4.2 & 92.0 & 148.3 & 77.9 \\
\hline 2015 & 22 & 168.0 & 179.1 & 186.8 & 2.90 & 5.4 & 0.1 & -8.5 & 92.8 & 150.1 & 79.1 \\
\hline 2016 & 23 & 169.5 & 180.6 & 190.8 & 2.75 & 5.3 & 2.1 & -3.2 & 93.5 & 152.8 & 81.2 \\
\hline 2017 & 24 & $172.0^{*}$ & $183.7^{*}$ & 196.5 & $2.70^{*}$ & 5.3 & 3.0 & 1.3 & 94.1 & 155.1 & $82.3^{*}$ \\
\hline 2018 & 25 & $174.0^{*}$ & $186.3^{*}$ & 201.6 & $2.65^{*}$ & 5.3 & 2.6 & 0.6 & $94.7^{*}$ & $158.6^{*}$ & $83.8^{*}$ \\
\hline
\end{tabular}

Sources: MFP: Productivity Surveys (Statistics of Finland, 2017) [11] (* are estimated by Table 4); GDP: World Economic Outlook Database (IMF, 2018) [15]; R\&D intensity: OECD Database (OECD, 2018) [16] (*are estimated based on trends in 2014-2016); Internet dependence: World telecommunication/ICT indicators database (ITU, 2018) [17] (*are estimated based on trends in 2014-2016); Final consumption: National Accounts of Finland (Statistics of Finland, 2018) [18] (*are estimated based on trends in 20142016); GTC/GC: National Accounts of Finland (Statistics of Finland, 2018) [18](*are estimated based on trends in 2014-2016).

First, SIRs substitution for GSC was analyzed. As reviewed in Section 1, since SIRs consists of the advancement of the Internet (that permeates into broad ICT in the digital platform economy) [19] [20], and GSC is centered on R\&D, equation (1) examines this substitution.

$$
\ln \frac{I}{R}=a_{\varepsilon}+\varepsilon_{j i} \ln \frac{p_{j}}{p_{i}}
$$

where $I$ : Internet dependence, $R: \mathrm{R} \& \mathrm{D}$ expenditure, $p_{i}$ : Internet price, $p_{j}: \mathrm{R} \& \mathrm{D}$ price, $\varepsilon_{j i}$ : elasticity of $I$ substitution for $R$, and $a_{\varepsilon}$ : coefficient. When $\varepsilon_{j i}>1, I$ substitute for $R$ [6]. 
International Journal of Managing Information Technology (IJMIT) Vol.10, No.4, November 2018

Table 5 summarizes the result of the analysis over the period of 1995-2018 which demonstrates statistically significant and supports the substitution hypothesis $\left(\varepsilon_{j i}>1\right)$ after the stagnation period.

Table 5. Correlation between I/R ratio and relative price in Finland (1995-2018).

$$
\begin{aligned}
& \ln \frac{I}{R}=-2.01+0.63 D_{1} \ln \frac{P_{j}}{P_{i}}+2.17\left(D_{2}+D_{3}\right) \ln \frac{P_{j}}{P_{i}}+3.34 D_{1}-0.13 D \quad \text { adj. } R^{2} 0.966 \mathrm{DW} 1.25
\end{aligned}
$$

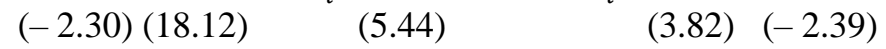

$D$ : dummy variables. $D_{I-} D_{3}:$ see Table 6; $D: 1999,2000=1$, others $=0$.

The figures in parentheses indicate the t-statistics: all are significant at the $1 \%$ level.

Second, spillover of this SIRs to GTC was analyzed by using Nadiri and Schankerman (1981) [13] approach that depicts MFP as a function of technology knowledge stock $(T)$, spill-over technology $(I)$, demand creation $(C)$, and learning effect $(\lambda)$ as follows:

$$
\begin{aligned}
M F P & =F(T, I, C, \lambda)=A^{\prime} e^{\lambda t} T^{\alpha} C^{\beta} I^{\gamma}=A e^{\lambda t} R^{\alpha} C^{\beta} I^{\gamma} \\
A & =\frac{A^{\prime}}{(\rho+g)^{\alpha}}
\end{aligned}
$$

where $A, A^{\prime}$ : scale factor, $\lambda$ : learning coefficient, $T$ : technology knowledge stock, $R$ : R\&D expenditure, $C$ : final consumption expenditure, $I$ : Internet dependence, $\alpha, \beta, \gamma$ : elasticity, $\rho$ : rate of obsolescence of technology, and $g: \mathrm{R} \& \mathrm{D}$ growth rate at the initial period.

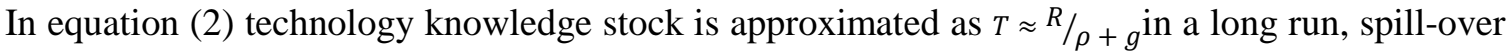
technology is represented by the Internet as the digital economy has augmented the permeation of the Internet into broad ICT [26], and demand creation is represented by final consumption expenditure.

Equation (2) can be developed as follows by taking logarithm:

$$
\ln M F P=\ln A+\lambda t+\alpha \ln R+\beta \ln C+\gamma \ln I
$$

Table 6 summarizes the result of the regression analysis over the period of 1994-2018 which demonstrates statistically significant.

Table 6. Governing factors of MFP in Finland (1994-2018).

$$
\begin{aligned}
& \ln M F P=-43.23-0.04 t+0.03 D_{1} \ln R-0.25\left(D_{2}+D_{3}\right) \ln R+1.80 \ln C \\
& (-6.01)(-6.71) \quad(2.75) \quad(-2.56) \quad \text { (7.23) } \\
& +0.04 D_{1} \ln I+0.84 D_{2} \ln I+8.96 D_{3} \ln I+38.89 D_{1}+36.87 D_{2}+0.02 D \text { adj. } R^{2} 0.983 D W 2.27 \\
& \begin{array}{lllll}
(1.75)^{* 1} & (1.87)^{* 1} & (6.27) & 6.22) & (5.78)
\end{array}
\end{aligned}
$$

$D$ : dummy variables identifying $\mathrm{R} \& \mathrm{D}$-driven economic features of respective periods as follows:

\begin{tabular}{llcccl}
\hline D: Dummy variables & $\begin{array}{c}1994- \\
2009\end{array}$ & $\begin{array}{c}2010- \\
2015\end{array}$ & $\begin{array}{c}2016- \\
2018\end{array}$ & \multicolumn{1}{c}{ Features of the period } \\
\hline$D_{1}$ & $1994-2009=1$, others $=0$ & 1 & 0 & 0 & $\begin{array}{l}\text { Sustainable increase in R\&D intensity that supported } \\
\text { economic growth }\end{array}$ \\
\hline$D_{2}$ & $2010-2015=1$, others $=0$ & 0 & 1 & 0 & R\&D intensity decline in the economic stagnation \\
\hline$D_{3}$ & $2016-2018=1$, others $=0$ & 0 & 0 & 1 & $\begin{array}{l}\text { Economic resurgence after the Competitiveness Pact despite } \\
\text { R\&D intensity decline }\end{array}$ \\
\hline
\end{tabular}

$D: 2000,2001,2007,2010,2011=1$, others $=0$,

The figures in parentheses indicate the t-statistics: all are significant at the $1 \%$ level except ${ }^{* 1} 10 \%$. 
International Journal of Managing Information Technology (IJMIT) Vol.10, No.4, November 2018

Looking at Table 6 we note that while $\mathrm{R} \& \mathrm{D}(R)$ and Internet-driven spillover technology $(I)$ together with demand $(C)$ made a balanced contribution to MFP increase before economic stagnation (19942009), this structure has substantially changed during the economic stagnation(2010-2015)and its resurgence after the Competitiveness Pact(2016-2018)as Internet-driven

spillover technology demonstrates a significant impact on MFP increase while R\&D increase reacted negatively in this period. This is conspicuous particularly after the Competitiveness Pact in 2016.

\subsection{MFP's CONTRIBUTION To GTC INCREASE}

With an understanding of MFP's significant contribution to GDP growth in Finland and also GTC's leading role in its economic recovery[10], following triangle structure can be anticipated as illustrated in Fig. 5:

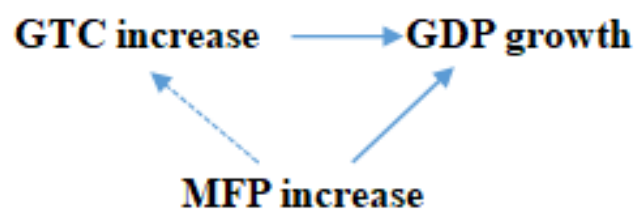

Figure 5. Triangle structure among GDP growth, MFP increase and GTC increase.

With this hypothetical view, MFP's possible contribution to GTC increase is examined using equation (3) that depicts MFP by its constitution.

Based on the empirical findings obtained from Table 6 and aiming at identifying the spill-over effect stimulated by the Competitiveness Pact, the analysis is conducted by imposing coefficient dummy variables on the spill-over effect before and after the Competitive Pact as depicted in equation (4). Backward elimination method with $10 \%$ criteria is used for the analysis.

$\ln K=\ln A+\lambda t+\alpha 1 D 1 \ln R+\alpha 2(D 2+D 3) \ln R+\beta \ln C+\gamma 1 D 1 \ln I+\gamma 2 D 2 \ln I+\gamma 3 D 3 \ln I+\delta 1 D 1+\delta 2 D 2$

where $K$ : share of GTC out of gross capital formation; $D$ : dummy variables (see Table 6).

Table 7 summarizes the result of the analysis over the period of 1994-2018 which demonstrates statistically significant and support the hypothetical view that MFP increase contributes to GTC increase.

Thus, Tables 6 and 7 demonstrate the significance of the triangle structure among GDP growth, MFP increase and GTC increase as anticipated by Fig. 5.

Table 7. Components of MFP impacting on GTC in Finland (1994-2018).

$$
\begin{aligned}
& \ln K=-10.87-0.01 t-0.11 \mathrm{D}_{1} \ln R+0.59 \ln C \\
& (-2.78)(-3.63)(-4.43) \quad(3.86) \\
& +1.15 D_{2} \ln I+2.77 D_{3} \ln I+12.68 D_{1}+7.34 D_{2}-0.01 D \text { adj. } R^{2} 0.922 \quad D W 1.58 \\
& \text { (4.90) (3.31) (3.34) (1.94)*1 }(-2.65)
\end{aligned}
$$

Backward elimination method with $10 \%$ criteria is used.

The figures in parentheses indicate the t-statistics: significant at the $1 \%$ level except $* 110 \%$. 
International Journal of Managing Information Technology (IJMIT) Vol.10, No.4, November 2018

In addition, Table 7 reveals that $I$ (Internet-driven spillover technology) demonstrates significant contribution to GTC increase while no significant contribution by $R(\mathrm{R} \& \mathrm{D}$ investment) to GTC increase during stagnation and resurgence periods $\left(D_{2}\right.$ and $\left.D_{3}\right)$. This is particularly conspicuous in the resurgence period after the Competitiveness Pact in 2016. This supports the preceding findings that SIRs substituted for GSC centered on R\&D during the stagnation period. SIRs spilled-over to GTC thereby contributed to GDP resurgence after the Competitiveness Pact(see Fig. 9 typical examples).

\section{Uncaptured Gdp's Function In Paving The Path For SUBSTITUTION}

The above analyses support the hypothetical view that Finnish resurgence in recent years can be attributed to SIRs substitution for GSC centred on R\&D [6] and SIRs spill-over to GTC (Table 7 and [6]) that contributed to removing structural impediments in GTC increase [5] which was the main contributor to GDP growth (Table 1).

Such substitution and spill-over have been enabled by the support of uncaptured GDP that has paved the path for this sophisticated function. Uncaptured GDP leverages SIRs through its coevolution with a shift in people's preferences to supra-functionality beyond economic value and advancement of the Internet induced by such a shift as illustrated in Fig. 1.

This section analyses this function.

GDP growth rate depends largely on MFP growth rate in Finland as demonstrated in Table 2.

$$
\frac{\Delta V}{V}=\mathrm{GGR}=a+b \mathrm{MFPGR}
$$

where: $V$ : GDP, $a$ and $b$ : coefficients (similar coefficients are used in the following equations). Integrating equation (5) with respect to time $t$,

$$
\ln V=a_{0}+a t+b \ln \mathrm{MFP}
$$

MFP is depicted as follows as reviewed earlier:

$$
\ln M F P=\ln A+\lambda t+\alpha \ln R+\beta \ln C+\gamma \ln I
$$

Based on consumption function, final consumption expenditure $C$ can be depicted as a function of $V$ as follows:

$$
\ln C=a^{*}+\lambda^{*} t+b^{*} \ln V
$$

Since SIRs depend largely on the advancement of the Internet $I$ [6][19] and substitute for GSC centred on $R$, following correlations can be depicted:

$$
\ln I=p+q \ln \frac{R}{V}
$$

Substituting MFP in equation (5') by equation (2) and also $C$ and $I$ in equation (2) by equations (6) and (7), respectively:

$$
\ln V=a_{0}+a t+b(\ln A+\lambda t+\alpha \ln R+\beta \ln C+\gamma \ln I)
$$


International Journal of Managing Information Technology (IJMIT) Vol.10, No.4, November 2018

$$
\begin{gathered}
=a_{0}+a t+b\left[\ln A+\lambda t+\alpha \ln R+\beta\left(a^{*}+\lambda^{*} \mathrm{t}+b^{*} \ln V\right)+\gamma\left(p+q \ln \frac{R}{V}\right)\right] \\
\left(1-b \beta b^{*}+b r q\right) \ln V=\left(a_{0}+b \ln A+b \beta a^{*}+b \gamma p\right)+\left(a+b \lambda+\beta \lambda^{*}\right) t+b(\alpha+\gamma q) \ln R
\end{gathered}
$$

Partial differentiate by $\ln R$

$$
\left(1-b \beta b^{*}+b \gamma q\right) \frac{\partial \ln V}{\partial \ln R}=b(a+\gamma q), \quad \frac{\partial \ln V}{\partial \ln R}=\frac{b}{1+b\left(\gamma q-\beta b^{*}\right)}(\alpha+\gamma q)
$$

Given that $T \approx R / \rho+g$ in a long run as depicted in equation (1), marginal productivity of technology can be estimated as follows:

$$
\frac{\partial V}{\partial T}=\left[\frac{b(\alpha+\gamma q)}{1+b\left(\gamma q-\beta b^{*}\right)}\right](\rho+g) \frac{V}{R}
$$

Equation (8) depicts that marginal productivity of technology is governed primarily by elasticity of SIRs to MFP $(\gamma)$ and R\&Dintensity to SIRs $(q)$ together with management strategy. Management strategy consists of R\&D productivity $(V / R)$ and planned obsolescence strategy (POS). POS manages pace and speed of R\&D investment $(\rho+\mathrm{g})$ taking into account of optimal lifetime of technology maximizing the profittability of $R \& D$ depending on its productivity [21][22].

\section{Note Estimate of final consumption and R\&D strategy}

\section{N1. Final consumption}

Table N1 Correlation between final consumption expenditure and GDP in Finland(1994-2017).

$$
\ln C=2.37+0.01 t+0.46 \ln V_{-1} \quad \text { adj. } R^{2} \quad 0.994 \quad D W 1.44
$$

$$
\text { (14.45) (13.36) (13.57) }
$$

The figures in parentheses indicate the t-statistics: all are significant at the $1 \%$ level.

\section{N2. R\&D strategy}

Table N2 Correlation between Internet dependence and R\&D intensity in Finland(1995-2018).

$$
\begin{aligned}
& \ln I=3.79+4.17 D_{1} \ln \frac{R}{V}-0.21\left(D_{2}+D_{3}\right) \ln \frac{R}{V}+14.58 D_{1}-0.40 D \text { adj. } R^{2} 0.963 D W 1.16 \\
& (2.88)(16.29) \quad(-9.58) \quad(9.17) \quad(-3.78)
\end{aligned}
$$

$D$ : dummy variables $\left(D_{1}: 1995-2009=1\right.$, others $=0 ; D_{2+} D_{3}: 2010-2018=1$, others $=0, D: 1999,2000=1$, others $=0$ ).

The figures in parentheses indicate the t-statistics: all are significant at the $1 \%$ level.

On the basis of the above empirical analyses, coefficients and elasticity of substitution governing marginal productivity of technology in Finland can be estimated as tabulated in Table 8. 
International Journal of Managing Information Technology (IJMIT) Vol.10, No.4, November 2018

Table 8. Coefficients and elasticity of substitution governing marginal productivity of technology in Finland (1994-2018).

\begin{tabular}{|c|c|l|c|c|c|}
\hline & & & $1994-2009$ & $2010-2015$ & $2016-2018$ \\
\hline$b$ & $\partial \ln \mathrm{V} / \partial \ln \mathrm{MEP}$ & MFP elasticity to GDP & 1.22 & 1.22 & 1.22 \\
\hline$b^{*}$ & $\partial \ln \mathrm{C} / \partial \ln \mathrm{V}$ & GDP elasticity to consumption & 0.46 & 0.46 & $0.46^{*}$ \\
\hline$\alpha$ & $\partial \operatorname{lnMFP} / \partial \ln \mathrm{R}$ & R\&D elasticity to MFP & 0.03 & -0.25 & -0.25 \\
\hline$\beta$ & $\partial \operatorname{lnMFP} / \partial \ln \mathrm{C}$ & Consumption elasticity to MFP & 1.80 & 1.80 & 1.80 \\
\hline$\gamma$ & $\partial \operatorname{lnMFP} / \partial \ln I$ & SIRs elasticity to MFP & 0.04 & 0.84 & 8.96 \\
\hline$q$ & $\partial \ln \mathrm{I} / \partial \ln (\mathrm{R} / \mathrm{V})$ & R\&D intensity elasticity to SIRs & $4.17^{\#}$ & -0.21 & -0.21 \\
\hline$\varepsilon$ & $\partial \ln (\mathrm{I} / \mathrm{R}) / \partial \ln \left(p_{j} / p_{i}\right)$ & Elasticity of SIRs substitution for R\&D & $0.63^{\#}$ & 2.17 & 2.17 \\
\hline
\end{tabular}

*Estimate by $2016-2017$ and "estimate by $1995-2009$.

Applying these estimated values to equation (8) trajectory of marginal productivity of technology in Finland can be estimated. Fig. 6 illustrates a plausible estimate of this trajectory. This was based on an assumption that dramatic change in $\gamma$ and $q$ as a consequence of SIRs substitution for R\&D would be absorbed by planned obsolescence strategy that seeks the stable level of profitability over the whole period examined ( $\rho+g$ was managed to smooth correspondence with).

Fig. 6 demonstrates that Finland depended on uncaptured GDP as a consequence of the digital economy [4] [8] and declined its marginal productivity of technology [20] which in turn activated firms to utilize SIRs [5]. Induced SIRs played a significant role in substituting for heavy R\&D investment (Table 5) that had become critical burden when nation's economy confronted a great stagnation due to the Lehman shock in 2008. This substitution transformed marginal productivity of technology with declining trend into that of growing trend from 2010. This trend further accelerated from 2016. This can be attributed to effective assimilation of SIRs that substituted for GSC dominated by R\&D. The impact has become conspicuous particularly after 2016 due to effective assimilation of SIRs that spilled-over to GTC (Table 7). This effective assimilation can be attributed to the Competitiveness Pact enacted in 2016 that played a trigger role in awaking Finnish latent sophisticated assimilation capacity leading to economic resurgence. As conclusion it is claimed that uncaptured GDP functioned in paving the path for SIRs which effectively removed structural impediments of GDP growth.

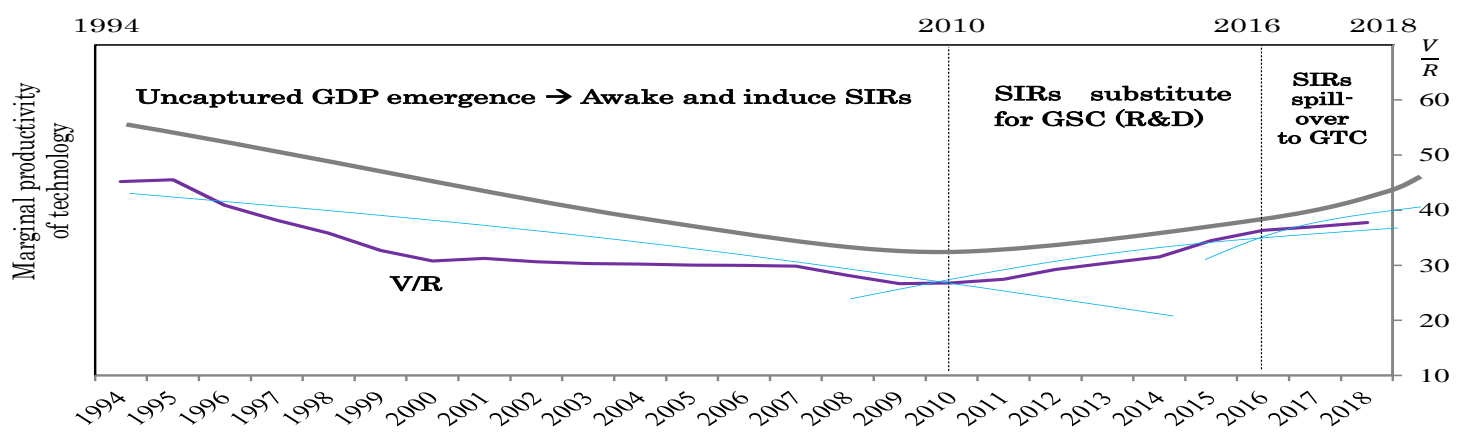

Figure 6. Trend in marginal productivity of technology in Finland (1994-2018)

-Uncaptured GDP function in paving the path for SIRs substitution and spillover role. 
International Journal of Managing Information Technology (IJMIT) Vol.10, No.4, November 2018

\section{Dynamism In Removing Structural ImPediments In GtC GROWTH}

Analyses in the preceding sections suggest the following dynamism of SIRs in removing structural impediments in GTC growth which contributed to resurgence of Finnish GDP growth [6] as illustrated in Fig. 7.

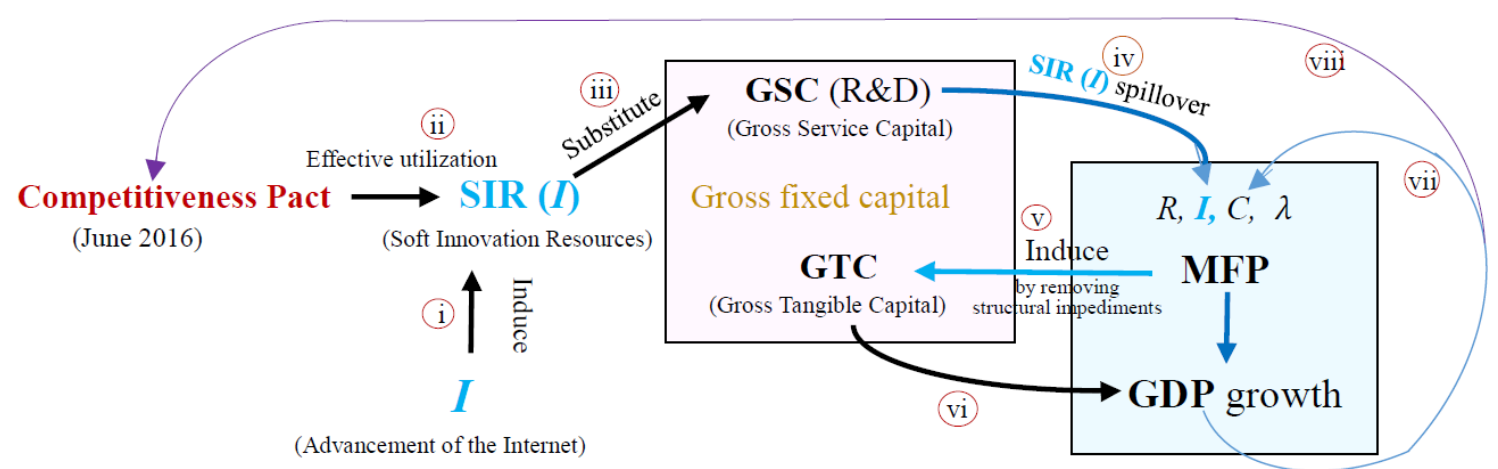

Figure 7. Dynamism of soft innovation resources (SIRs) in removing structural impediments in GTC growth in Finland.

(i) Advancement of the Internet awoke and induced SIRs (Fig. 1).

(ii) The Competitiveness Pact spurred effective utilization of SIRs (see below).

(iii) SIRs substituted for GSC (cantered by R\&D) supported by uncaptured GDP (Table 6).

(iv) Trough the substitution process SIRs spilled-over and incorporated in GTC via MFP (Table 5).

(v) MFP induced GTC by removing structural impediments of its increase (Table 7).

(vi) Increased GTC contributed to GDP growth (Table 1).

(vii) GDP growth in turn increased MFP (Table 3) leading to a virtuous cycle.

(viii) In addition, GDP resurgence instilled confidence to the Competitiveness Pact.

Effective utilization of SIRs as well as dynamism of its substitution for GSC and incorporation of spill-over SIRs in GTC depends largely on co-evolutionary acclimatization capacity of the nation [23].

The dynamism in creating this capacity can be conceptualized as follows (Fig. 8). Activation of this dynamism can be attributed to Finnish institutional elasticity and spurred by the Competitiveness Pact and stimulated by economic resurgence triggered by the Competitiveness Pact.

(i) Cumulative learning cultivates the capacity of distinguishing technology spillover flows by assessing and selecting them into $(a)$ should learn, $(b)$ should not learn, and $(c)$ can not learn.

(ii) This distinguishing capacity leads to absorptive capacity to be able to treat accepted spillover technologies homogeneous to Finland's own technology stock.

(iii) Through co-evolutionary exercise of absorption assimilation capacity can be developed thereby able to embody absorbed technology to whole system in production, diffusion, and consumption.

(iv)This ability then develops to domestication thereby taming assimilated spillover technology into the whole institutional system by activating it through convincing and empowering all stakeholders. 
International Journal of Managing Information Technology (IJMIT) Vol.10, No.4, November 2018

(v) Domesticated technology/knowledge in turn further improve distinguishing capacity, absorption, assimilation and domestication ability in a co-evolutionary way, thus coevolutionary acclimatization capacity can be created.

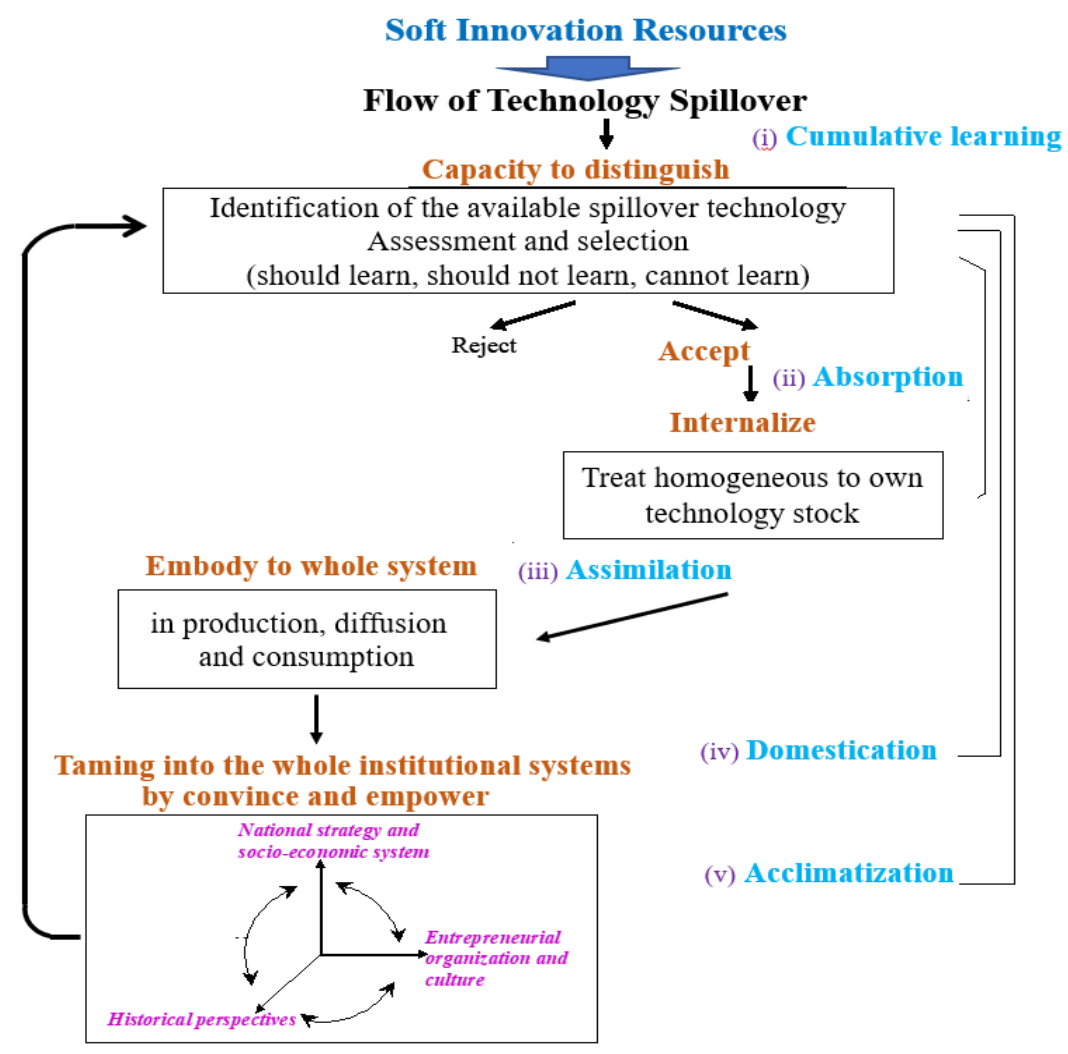

Figure 8 . The concept of co-evolutionary acclimatization creation dynamism.

As stated earlier, traditionally Finland has been good at crises management. It transformed external crises into a springboard for new innovation by substituting innovation for constrained resources [3]. It has indigenously incorporated sophisticated institutional elasticity to activate this notable capacity [4]. However, this elasticity depends on trust among stakeholders (business circles, customers, and public authorities) as has been explicitly demonstrated by the contrast of success and legal battles of Uber's global expansion [24].

Finland's elastic institutional systems have been long subdued by the aftermath of the global stagnation due to the Lehman shock in 2008.

While Finland demonstrates higher trusting relationship than its ICT rival Singapore, it suffers rigid non-flexible labor-employer relations and also the world's most rigid wage determination as compared in Table 9 [5]. This rigid system urged to freeze its institutional elasticity resulting in seven long years economic stagnation. 
International Journal of Managing Information Technology (IJMIT) Vol.10, No.4, November 2018

Table 9. Noteworthy contrast in institutional elasticity between Finland and Singapore (2017).

\begin{tabular}{|c|c|c|c|}
\hline Soft innovation resources & Finland & Singapore & References \\
\hline $\begin{array}{l}\text { Trusting relationship } \\
\text { Willingness to delegate authority } \\
\text { Trust in teachers (2013 out of } 21 \\
\text { countries) }\end{array}$ & $\begin{array}{l}4 \\
2\end{array}$ & $\begin{array}{c}17 \\
7\end{array}$ & $\begin{array}{l}\text { The Global Competitiveness } \\
\text { Report 2017-2018 (WEF, 2018) } \\
\text { Global Teachers Status Index } \\
\text { (Varkey Gems Foundation, 2014) }\end{array}$ \\
\hline $\begin{array}{l}\text { Labor-employer relations } \\
\text { Cooperation in labor-employer relations } \\
\text { Flexibility of wage determination }\end{array}$ & $\begin{array}{c}22 \\
137\end{array}$ & $\begin{array}{l}2 \\
5\end{array}$ & $\begin{array}{l}\text { The Global Competitiveness } \\
\text { Report 2017-2018 (WEF, 2018) } \\
\text { The Global Competitiveness } \\
\text { Report 2017-2018 (WEF, 2018) }\end{array}$ \\
\hline
\end{tabular}

Figures indicate world rank out of 140 countries otherwise indicated

In light of such long lasting stagnation and understanding of the significant role of trust, after years of negotiations and strikes, Finland government convinced the country's unions in June 2016 to accept the reform pact (Competitiveness Pact). The objective of this Pact is to improve Finnish companies' price competitiveness, increase exports and employment, and accelerate economic growth. With this objective this Pact leads to the increase of annual working hours, lower holiday bonuses, freeze wages for a year and increase pension contributions for workers while lowering them for employers. The government has promised to sweeten the deal with tax cuts. Prime Minister Juha Sipila pledged that Finland would be able to reduce unit labor costs to the same level as Sweden's in 2017, and to that of Germany's in three years. He also argued that greater business competitiveness would help generate new jobs (14 June 2016). This pledge was supported by the Governor at the Bank of Finland Erkki Liikanen in his statement on 31 March 2017 that the Competitiveness Pact was forecasted to improve cost competitiveness considerably. The Finnish economy posted $2.7 \%$ of GDP growth in 2017, higher than eurozone, Sweden (2.4\%) and Germany (2.5\%). At the end of 2017 Oli Rehn, a board member of the Bank of Finland, reported proudly that the mood in the country had changed in a year from entrenched pessimism to half euphoria which reflected in people's mood.

This historic ambitious decision in June 2016 to shift away from centralized wage-setting toward company-level labor deals can largely be appreciated as a consequence of effective utilization of SIRs, particularly of trust [25]. People's non-pessimistic mood with actual economic evidences has increased confidence to the Pact as illustrated in Fig. 9 and awaken nation's latent ability of sophisticated co-evolutionary acclimatization as illustrated in Fig. 8.

While the full-fledged effects of the Competitiveness Pact should be expected, hence further careful assessment should be indispensable. Some noteworthy signals to activate SIRs in removing structural impediments in GTC increase can be observed as illustrated in Fig. 7 and effects of SIRs spillover has become reality as demonstrated in Fig. 9. 
International Journal of Managing Information Technology (IJMIT) Vol.10, No.4, November 2018

\begin{tabular}{|c|c|c|c|}
\hline \multirow{2}{*}{$\begin{array}{l}\text { Gross } \\
\text { tangible } \\
\text { capital }\end{array}$} & \multicolumn{2}{|c|}{ Effects of SIR spillover } & \multirow{3}{*}{$\begin{array}{l}\text { Soft innovation } \\
\text { resources (SIR) }\end{array}$} \\
\hline & $\begin{array}{l}\text { Structural } \\
\text { impediments }\end{array}$ & $\begin{array}{l}\text { Way of } \\
\text { removal }\end{array}$ & \\
\hline Machinery & \multirow{4}{*}{$\begin{array}{c}\begin{array}{c}\text { Rigid wage } \\
\text { determination }\end{array} \\
\text { Imbalance of } \\
\text { employers demand }\end{array}$} & \multirow{4}{*}{$\begin{array}{c}\begin{array}{c}\text { Reform Pact } \\
\text { (June 2016) }\end{array} \\
\text { Elastic labor supply } \\
\begin{array}{c}\text { Gender balance } \\
\text { improvement }\end{array}\end{array}$} & \\
\hline Vehicles & & & $\begin{array}{l}\text { Driving force of preferences } \\
\text { shift to supra-functionality }\end{array}$ \\
\hline & & & Sleeping resources \\
\hline Plant & & & $\begin{array}{l}\text { Trust by overdrawing past } \\
\text { information }\end{array}$ \\
\hline Dwellings & Aging society & Sharing economy & $\begin{array}{l}\text { Utmost gratification ever } \\
\text { experienced }\end{array}$ \\
\hline $\begin{array}{l}\text { Buildings and } \\
\text { structures }\end{array}$ & $\begin{array}{c}\text { Demand supply } \\
\text { discrepancy }\end{array}$ & $\begin{array}{c}\text { On demand supply } \\
\text { Transgenerational } \\
\text { satisfaction }\end{array}$ & $\begin{array}{l}\text { Memory and future dream } \\
\text { Untapped resources and } \\
\text { vision }\end{array}$ \\
\hline $\begin{array}{l}\text { Land } \\
\text { improvements }\end{array}$ & $\begin{array}{l}\text { Preferences } \\
\text { diversification }\end{array}$ & & \\
\hline
\end{tabular}

Figure 9. Effects of soft innovation resources spillover.

As a consequent of such efforts, demand-supply discrepancy has dramatically decreased [26][27] and enable da GTC positive contribution to GDP growth. For example, machinery and equipment has changed from long lasting negative contribution to positive contribution to GDP growth from 2016 as: $-0.06 \%$ (2013), $-0.04 \%$ (2014), $-0.03 \%$ (2015) to $0.05 \%$ in 2016 [20][28]. Efforts for gender balance improvement by utilizing ICT advancement have contributed to improving the imbalance of employers demand [29]. Recent policy decisions of relaxation of car inspection laws (May 2018) and taxi market liberalization (July 2018) accelerate effective utilization of such SIRs as the driving force of preferences shift to supra-functionality [8] and sleeping resources [30]. These decisions are expected to remove demand supply discrepancy toward the aging society and people's preferences diversification and enable on demand supply and trans generational satisfaction [31].

\section{CONCLUSION}

In light of a notable resurgence in Finland which transformed interlaced contrast in world digital leaders: high welfare with low GDP growth in Finland and higher GDP growth with lower welfare in Singapore, dynamism enabling this resurgence was analyzed.

An empirical analysis focusing on the interactions among factors contributing to GDP growth and their constitutes over the last quarter century and also effects of the policy change such as the Competitiveness Pact enacted in June 2016 on the resurgence was conducted.

Noteworthy findings include:

(i) Finland highly depends on MFP growth for its GDP growth. 
International Journal of Managing Information Technology (IJMIT) Vol.10, No.4, November 2018

(ii) MFP consists of contribution of Finland's own R\&D, spillover technology, learning effects and final demand creation.

(iii) Finland has accomplished its GDP resurgence notwithstanding R\&D decreases.

(iv) This can be attributed to soft innovation resources (SIRs) induced by advancement of the Internet.

(v) SIRs substituted for gross service capital (GSC centered on R\&D) which created uncaptured GDP.

(vi) Through this substitution process SIRs spilled-over and incorporated in gross tangible capital (GTC) via MFP.

(vii) Uncaptured GDP paved the path for this substitution and spillover.

(viii) MFP induced GTC by removing structural impediments impeding its growth.

(ix) Increased GTC contributed to GDP growth, and grown GDP in turn increased MFP thereby a virtuous cycle has been constructed.

(x) This dynamism can be attributed to effective assimilation of spillover technology initiated by SIRs.

(xi) While Finland has indigenously incorporated sophisticated institutional elasticity to transform critical circumstances into a springboard for innovation, this elastic system has been long subdued by the aftermath of the global simultaneous stagnation in 2008.

(xii) Contrary to high level of trust relationship, Finland suffered rigid non-flexible labor-employer relations and also the world's most rigid wage determination.

(xiii) This rigid system urged to freeze Finland's own institutional elasticity resulting in seven long years stagnation.

(xiv) The ambitious historic decision of the Competitiveness Pact in June 2016, which aimed at overcoming such a crucial situation and shifting away from centralized wage-setting and toward company-level labor deals, can largely be appreciated as a consequence of effective utilization of SIRs, particularly of trust.

(xv) This Pact revitalized Finland's latent ability of co-evolutionary acclimatization and enabled effective utilization of SIRs leading to the above virtuous cycle for GDP resurgence.

These findings give rise to the following insightful suggestions for optimal trajectory management in the digital economy at both national and firm levels:

(i) Further exploration and utilization of new SIRs should be continued.

(ii) Details of uncaptured GDP's role in paving the path for substitution and spillover should be analyzed.

(iii) Effective mechanism of SIRs substitution for GSC (IPP) should be developed.

(iv) Optimal balance between SIRs dependence and sustainable GSC should be sought.

(v) Effective spillover of SIRs to GTC and its effective assimilation should be developed.

(vi) Similar substitution mechanism in reactivation of exports and consumption should be analyzed.

New innovation mechanism as SIRs substitute for GSC centered on R\&D and then spillover to GTC for removing structural impediments for growth could be a new innovation model in the digital economy. An insightful suggestion in overcoming a productivity paradox in the digital economy was thus provided.

Future works should focus on further exploration of additional SIRs and their quantification. Comparative assessment of SIRs depending on institutional systems is another priority issue. International comparisons thereon should also be undertaken. In addition, careful monitoring of the reversal trend should be continued. Successive assessment of the effects of the Competitiveness Pact should also be continued. 
International Journal of Managing Information Technology (IJMIT) Vol.10, No.4, November 2018

\section{ACKNOWLEDGEMENTS}

The research leading to these results is the part of a project: Platform Value Now: Value capturing in the fast emerging platform ecosystems, supported by the Strategic Research Council at the Academy of Finland [grant number 293446].

\section{REFERENCES}

[1] Department of Broadband, Communications and the Digital Economy (DBCDE), (2009) Digital Economy Future Directions, DBCDE, Camberra.

[2] Watanabe, C., Naveed, K. \& Zhao, W., (2015a) "New Paradigm of ICT Productivity: Increasing Role of Un-captured GDP and Growing Anger of Consumers," Technology in Society, Vol.41, pp 21-44.

[3] Watanabe, C., Naveed, K. \& Neittaanmäki, P., (2015b) "Dependency on Un-captured GDP as a Source of Resilience beyond Economic Value in Countries with Advanced ICT Infrastructure: Similarities and Disparities between Finland and Singapore,” Technology in Society, Vol. 42, pp 104-122.

[4] Watanabe, C., Naveed, K., Neittaanmäki, P. \& Tou, Y., (2016) "Operationalization of Un-captured GDP: The Innovation Stream under New Global Mega-trends," Technology in Society, Vol. 45, 58-77.

[5] Watanabe, C., Moriya, K., Tou, Y. \& Neittaanmäki, P., (2018b) "Consequences of the Digital Economy: Transformation of the Growth Concept," International Journal of Managing Information Technology, Vol. 10, No. 2, pp 21-39.

[6] Tou, Y., Moriya, K., Watanabe, C., Ilmola, L. \& Neittaanmäki, P., (2018) "Soft Innovation Resources: Enabler for Reversal in GDP Growth in the Digital Economy," International Journal of Managing Information Technology, Vol. 10, No. 3, in print.

[7] World Economic Forum (WEF), (2017) The Global Information Technology Report, 2017, WEF, Geneva.

[8] Watanabe, C., Tou, Y. \& Neittaanmäki, P., (2018c) "A New Paradox of the Digital Economy: Structural Sources of the Limitation of GDP Statistics," Technology in Society, in print.

[9] Ylhainen, I., (2017) Challenges of Measuring the Digital Economy. https://www.sitra.fi/en/articles/challenges-measuring-digital-economy/

[10] McDonagh, D., Satisfying Needs beyond the Functional: The Changing Needs of the Silver Market Consumer. Presented at the International Symposium on the Silver Market Phenomenon - Business Opportunities and Responsibilities in the Aging Society, Tokyo, Japan.

[11] Statistics Finland, (2017) "Productivity Surveys," Statistics Finland, Helsinki.

[12] Balcerzak, A.P. and Pietrzak, M.B., (2016) "Quality of Institutions and Total Factor Productivity in the European Union," Statistics in Transition, Vol. 17, No. 3, 497-514.

[13] Nadiri, M.I. and Schankerman, M.A. (1981) "The Structure of Production, Technological Change, and the Rate of Growth of Total Factor Productivity in the U.S. Bell System. In T.G. Cowing and R.E. Stevenson (eds.) Productivity Measurement in Regulated Industries (Economic Theory, Econometrics, and Mathematical Economics) 219-247. Academic Press, New York. 
International Journal of Managing Information Technology (IJMIT) Vol.10, No.4, November 2018

[14] Milne, L., (2017) "Finland Nurses Its Economy Back to Health," EU Economy. https://www.ft.com/content/73d66498-e19d-11e7-a8a4-0a1e63a52f9c

[15] IMF, (2018) “World Economic Outlook Database,” IMF, Washington.

[16] OECD, (2018) “OECD Database,” OECD, Paris.

[17] International Telecommunication Union (ITU), (2018) "World Telecommunication/ICT Indicators database, "ITU, Geneva.

[18] Statistics Finland, (2018a) "National Accounts of Finland," Statistics Finland, Helsinki.

[19] Naveed, K., Watanabe, C. \& Neittaanmäki, P., (2018) "The Transformative Direction of Innovation toward an IoT-based Society: Increasing Dependency on Uncaptured GDP in Global ICT Firms," Technology in Society, Vol. 53, pp 23-46.

[20] Watanabe, C., Moriya, K., Tou, Y. \& Neittaanmäki, P., (2018a) "Structural Sources of a Productivity Decline in the Digital Economy," International Journal of Managing Information Technology, Vol. 10, No. 1, pp 1-20.

[21] Bulow, J., (1986) “An Economic Theory of Planned Obsolescence,” Quarterly Journal of Economics, Vol. 101, 729-749.

[22] Aladeojebi, T.K., (2013) "Planned Obsolescence," International Journal of Scientific \& Engineering Research, Vol. 4, No. 6, 1504-1508.

[23] Chew, M., Watanabe, C. \& Tou, Y., (2010) "Technology Leapfrogging: Findings from Singapore's Water Industry," Journal of Technology Management for Growing Economies, Vol. 1, No. 2, 29-47.

[24] Watanabe, C., Naveed, K., Neittaanmäki, P., Fox, B., (2017) "Consolidated Challenge to Social Demand for Resilient Platforms: Lessons from Uber's Global Expansion," Technology in Society, Vol. 48, 3353.

[25] Watanabe, C., Naveed, K. \& Neittaanmäki, P., (2016b) "Co-evolution between Trust in Teachers and Higher Education toward Digitally-rich Learning Environments," Technology in Society, Vol. 48, pp 70-96.

[26] OECD, (2017) "OECD Review of Innovation Policy: Finland Assessment and Recommendation," OECD, Paris.

[27] Statistics Finland, (2018c) “The Labor Market in Finland," Statistics Finland, Helsinki.

[28] Statistics Finland, (2018d). "Statistics Finland's PX-Web databases," Statistics Finland, Helsinki.

[29] Watanabe, C., Naveed, K. \& Neittaanmäki,P., (2017) "ICT-driven Disruptive Innovation Nurtures Uncaptured GDP: Harnessing Woemen's Potential as Untapped Resources,” Technology in Society, Vol. 51, pp 81-101.

[30] Watanabe, C., Naveed, K., Neittaanmäki, P. \&Tou, Y., (2016a) "Co-evolution of Three Mega Trends Nature Uncaptured GDP: Uber's Ride-sharing Revolution," Technology in Society, Vol.46, pp 164185 . 
International Journal of Managing Information Technology (IJMIT) Vol.10, No.4, November 2018

[31] Naveed, K., Watanabe, C. \& Neittaanmäki, P., (2017) "Co-evolution between Streaming and Live Music Leads a Way to the Sustainable Growth of Music Industry: Lessons from the US Experiences," Technology in Society, Vol. 50, pp 1-19.

\section{AUTHORS}

Yuji Tou graduated from Tokyo Institute of Technology, Japan, and is currently specially appointed associate professor at Tokyo Institute of Technology, Japan (tou.yuji@gmail.com).

Chihiro Watanabe graduated from the University of Tokyo, Japan, and is currently Professor Emeritus at the Tokyo Institute of Technology, research professor at the University of Jyväskylä, Finland, and a research scholar at the International Institute for Applied Systems Analysis (IIASA). (watanabe.c.pqr@gmail.com).

Leena Ilmola graduated from Aalto University School of Science and Technology, Finland, and now is currently Senior Researcher at the International Institute of Technology (IIASA), Austria (ilmola@iiasa.ac.at)

Kuniko Moriya graduated from Aoyama Gakuin University, Japan, and is currently Director of the Bank of Japan, and a research scholar at the University of Jyväskylä, Finland (kuniko.moriya@boj.or.jp).

Pekka Neittaanmäki graduated from the University of Jyväskylä with a degree in Mathematics. He is currently Professor of the Faculty of Information Technology, University of Jyväskylä, Finland. (pekka.neittaanmaki@jyu.fi). 